Revista Brasileira de Farmacognosia Brazilian Journal of Pharmacognosy 21(6): 936-942, Nov./Dec. 2011

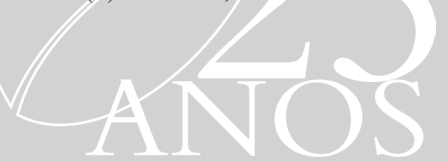

Article

Received 4 Oct 2010

Accepted 10 Jan 2011

Available online 26 Aug 2011

Keywords:

aerial parts

Ageratum fastigiatum

Asteraceae

essential oils

Eupatorieae

ISSN 0102-695X

http://dx.doi.org/10.1590/S0102-

695X2011005000151

\section{Contribution for the phytochemical studies of Ageratum fastigiatum}

\author{
Lucas D. Gonçalves, ${ }^{1}$ Hugo R. Almeida, ${ }^{1}$ Patrícia M. de \\ Oliveira, ${ }^{2}$ Norberto P. Lopes, ${ }^{3}$ Izabel C. C. Turatti, ${ }^{3}$ Fernando \\ C. Archanjo, ${ }^{1}$ Cristiane F. F. Grael ${ }^{*}, 1$
}

\author{
'Departamento de Farmácia, Faculdade de Ciências Biológicas e da Saúde, \\ Universidade Federal dos Vales do Jequitinhonha e Mucuri, Brazil, \\ ${ }^{2}$ Departamento de Química, Faculdade de Ciências Exatas e Tecnológicas, \\ Universidade Federal dos Vales do Jequitinhonha e Mucuri, Brazil, \\ ${ }^{3}$ Núcleo de Pesquisa em Produtos Naturais e Sintéticos, Faculdade de Ciências \\ Farmacêuticas de Ribeirão Preto, Universidade de São Paulo, Brazil.
}

\begin{abstract}
Organic extracts from leaves plus branches plus inflorescences of Ageratum fastigiatum (Gardner) R. M. King \& H. Rob., Asteraceae, were fractionated through classic chromatography. The steroids stigmasterol, chondrillasterol and campesterol were isolated from hexane extract. The triterpenes lupeol, taraxasterol, $\alpha$-amyrin, $\beta$-amyrin, pseudotaraxasterol, lupeol acetate and $\alpha$-amyrin acetate were isolated from ethyl acetate extract. Steroids and triterpenes were identified by GC-MS. The coumarin ayapin was isolated from ethanol extract and identified by NMR. Essential oils of the fresh leaves and fresh inflorescences were obtained by hydrodistillation and analyzed for GC-MS. The main components in both essential oils were $\alpha$-pinene, limonene and germacrene D.
\end{abstract}

\section{Introduction}

Species Ageratum fastigiatum (Gardner) R. M. King \& H. Rob., Asteraceae, can be found in antropogenically disturbed areas and, more frequently, in natural areas of the plateau of Diamantina city in Minas Gerais State (Serra do Espinhaço), paths of Triângulo Mineiro, Serra da Mantiqueira, among other Brazilian places (Guimarães et al., 2002; Almeida et al., 2004).

The plant is used in popular medicine of several regions known as "matapasto" (Del-Vechio-Vieira et al., 2008). In Diamantina is also denominated "enxota" by the healers who prepare extract using leaves and branches (with or without inflorescences) fresh crushed or torn and submitted to maceration with water for some hours. The aqueous extract, after filtration, is applied topically to treat pain and inflammations (Gonçalves et al., 2007).

Phytochemical studies accomplished with this medicinal species indicated the presence of triterpenes, diterpenes, sesquiterpenes and coumarins in organic extracts from roots and aerial parts of the plant (Bohlmann et al., 1981; Bohlmann et al., 1983). The analysis of essential oils of this species revealed the sesquiterpenes prevalence; however, qualitative and quantitative differences are observed in their composition when derived from different tissues or individuals (Del-Vechio-Vieira et al., 2009a; DelVechio-Vieira et al., 2009b). Those variations in secondary metabolites are influenced by intrinsic factors (genetics, development, growth, vegetable organ) and extrinsic (atmospheric conditions, geographic region, soil type, presence of predators or pathogens, among other environmental factors) to plants (Lima et al., 2003; Castro et al., 2004; Gobbo-Neto \& Lopes, 2007). Studies on the biological potential of essential oils and polar extracts of A. fastigiatum revealed antimicrobial, analgesic and anti-inflammatory activities (Del-VechioVieira et al., 2007; Del-Vechio-Vieira et al., 2009a; Del-Vechio-Vieira et al., 2009b). In spite of other published works, variations in metabolism reported in these researches, and because it is a medicinal plant, stimulate the restudy of the chemical composition of $A$. fastigiatum, collected in Diamantina region.

\section{Materials and Methods}

\section{Plant material}

For the obtaining of organic extracts, aerial parts (branches with leaves plus inflorescences) of 
Ageratum fastigiatum (Gardner) R. M. King \& H. Rob., Asteraceae, were collected in December of 2006, in JK Campus UFVJM (S 18².220' W 4334.720', altitude $1250 \mathrm{~m}$ ), in the city of Diamantina-MG. Another collection of aerial parts was accomplished in April of 2008, at the same site, in the morning (before 9:00 o'clock), for extraction of essential oil. Voucher specimen was deposited in the DIA Herbarium/ UFVJM (Diamantina-MG, Brazil), under the No. 1300 and their identification was made by Dr. Carlos Victor Mendonça Filho and Dr. Fabiane Nepomuceno Costa (Departamento de Ciências Biológicas/FCBS/ UFVJM).

\section{Preparation of organic extracts}

Aerial parts of $A$. fastigiatum were dried in the shade at room temperature until constant weight and later triturated. The dried powdered material (500 g) was macerated successively with $n$-hexane, ethyl acetate and ethanol $(3: 1 \mathrm{w} / \mathrm{v}$ - solvents Vetec analytical degree) at room temperature for three days in each solvent. Each macerate was separated by filtration and concentrated under vacuum in a rotatory evaporator Fisatom 801 (below $40{ }^{\circ} \mathrm{C}$ ) to give the dried crude extracts: $7.03 \mathrm{~g}$ (hexane extract), $20.10 \mathrm{~g}$ (ethyl acetate extract) and $16.12 \mathrm{~g}$ (ethanol extract).

General experimental procedures for isolation of constituents from the organic extracts

In the processes of classic column chromatography (CCC) was used as stationary phase the silica gel 60 (35-70 mesh - Vetec) and as mobile phase the $n$-hexane, ethyl acetate, ethanol or methanol (Vetec or Dinâmica) and mixtures of those solvents in a growing gradient of polarity.

The processes of fractionation of the crude extracts, as well as their fractions, were monitored by comparative thin layer chromatography (TLC) having as objectives the observation of the purity degree of products of fractionation and detection of fractions with similar chromatographic profiles, for its subsequent combination. For both, were used chromatoplates of aluminum covered with silica gel 60 with fluorescence indicator (Macherey-Nagel - $\mathrm{UV}_{254}$ ), several eluents systems and different revealing agents (Wagner \& Bladt, 1996).

Isolation and identification of constituents from the organic extracts

The hexane extract $(4.50 \mathrm{~g})$ was fractioned through CCC giving 164 fractions of $30 \mathrm{~mL}$, that were combined into seventeen fractions (Ia-XVIIa).
The fraction IXIa $(87 \mathrm{mg})$, obtained by grouping of fractions 53 to 59 (eluted with hexane/ethyl acetate $8: 2)$ was submitted to CCC. From the preparative chromatography resulted 49 fractions of $5 \mathrm{~mL}$, pooled into fifteen fractions ( $\mathrm{Ib}-\mathrm{XVb})$. Of those fractions, $\mathrm{Xb}$ (9 $\mathrm{mg}$ ), resulting from the combination of fractions 10 and 11 (eluted with hexane/ethyl acetate 7:3), was analyzed through a chromatography system in gaseous phase coupled to a mass spectrometry (GC-MS). The analysis was performed using Shimadzu-QP2010 equipment, with capillary column DB-5MS Agilent (30 $\mathrm{m} \times 0.25 \mathrm{~mm}$, film thickness $0.25 \mu \mathrm{m}$ ), under the following conditions: Helium was used at pressure of $182.20 \mathrm{kPa}$, with flow of $1.50 \mathrm{~mL} / \mathrm{min}$; temperature in the injector was $260{ }^{\circ} \mathrm{C}$; the initial temperature of the column was $250{ }^{\circ} \mathrm{C}$ staying for $12 \mathrm{~min}$, increasing to $280{ }^{\circ} \mathrm{C}\left(6{ }^{\circ} \mathrm{C} / \mathrm{min}\right)$ and being conserved by $20 \mathrm{~min}$. The ionization mode used was the electronic impact at 70 $\mathrm{eV}$. The 5- $\alpha$-cholestane (Sigma) was used as internal standard, being calculated the relative retention (RR) of each constituent of the analyzed mixture (McNair $\&$ Bonelli, 1969). The constituents of the sample were identified through the analysis of their mass spectra and for comparison of their RR with RR standards of steroids (Supelco). The quantification of each constituent of the mixture was accomplished through the relative area of the chromatogram peaks.

The ethyl acetate extract $(20.10 \mathrm{~g})$ was suspended in $400 \mathrm{~mL}$ of a mixture of methanol/distilled water $4: 1$, being filtered and being obtained a solid residue $(5.12 \mathrm{~g})$. The hydroalcoholic filtrate was submitted to partition with $3 \times 100 \mathrm{~mL} n$-hexane (Vetec) to separate non-polar compounds that could be present in it. Soon, the hydroalcoholic phase was partitioned with $3 \times 100$ $\mathrm{mL}$ chloroform (Vetec). Thus were obtained the hexane, chloroform and hydroalcoholic phases. The chloroform and hexane phases were concentrated in rotatory evaporator (around $40{ }^{\circ} \mathrm{C}$ ) obtaining dried material: $721 \mathrm{mg}$ and $11.18 \mathrm{~g}$, respectively. The hydroalcoholic phase was concentrated in rotatory evaporator at $40{ }^{\circ} \mathrm{C}$ (the methanol was removed) and then it was lyophilized (lyophilizer L101/Liotop), obtaining $3.08 \mathrm{~g}$ of dried material. Ten grams of chloroform phase were chromatographed (CCC), resulting in 143 fractions of $40 \mathrm{~mL}$, pooled into nine fractions (Ic-IXIc). The fraction VIc $(431 \mathrm{mg})$, resulting from the combination of the fractions 76 to 81 (eluted with hexane/ethyl acetate 2:8), was fractioned by CCC, resulting in 105 fractions of $15 \mathrm{~mL}$. The chromatographic analyses (TLC) of those 105 fractions resulted in the grouping into eight fractions (Id-VIIId). The fraction VId (25 $\mathrm{mg}$ ), resulting from the combination of the fractions 60 to 76 (eluted with ethyl acetate), was analyzed by GCMS. The analysis was performed in Shimadzu-QP2010 equipment, with capillary column DB-17 Agilent (30 
$\mathrm{m} \times 0.25 \mathrm{~mm}$, film thickness $0.25 \mu \mathrm{m}$ ), under the following conditions: Helium was used at pressure of $114.10 \mathrm{kPa}$, with flow of $1.40 \mathrm{~mL} / \mathrm{min}$; the temperature in the injector was of $260{ }^{\circ} \mathrm{C}$; the initial temperature of the column was $120{ }^{\circ} \mathrm{C}$, rising to $260{ }^{\circ} \mathrm{C}$ to $20{ }^{\circ} \mathrm{C} /$ min (staying $5 \mathrm{~min}$ ), increasing to $280{ }^{\circ} \mathrm{C}$ to $2{ }^{\circ} \mathrm{C} / \mathrm{min}$ (being conserved by $9 \mathrm{~min}$ ), arriving up to $290{ }^{\circ} \mathrm{C}$ to 2 ${ }^{\circ} \mathrm{C} / \mathrm{min}$ (staying for $20 \mathrm{~min}$ ). The ionization mode used was the electronic impact at $70 \mathrm{eV}$. The 5 - $\alpha$-cholestane (Sigma) was used as internal standard. The constituents of the sample that were identified through the analysis of their mass spectra and by comparison of their RR calculated with RR standards of triterpenes (isolated from extracts of several plants which were identified through $\mathrm{NMR}^{1} \mathrm{H}$ and ${ }^{13} \mathrm{C}$ presented good degree of purity). The quantification of each constituent of the mixture was accomplished through the relative area of the chromatogram peaks.

The preparative chromatography (CCC) of the ethanol extract $(9,30 \mathrm{~g})$ yielded 222 fractions of 40 $\mathrm{mL}$, grouped into eighteen fractions (Ie-XVIIIe). The fraction VIIIe $(129 \mathrm{mg})$, resulting from combination of the fractions 60 to 68 (eluted with hexane/ethyl acetate $7: 3$ ), was submitted to recrystallization with hexane and drops of ethyl acetate and ethanol. From fraction VIIIe were obtained $30 \mathrm{mg}$ of colorless crystals, analyzed by NMR. The NMR ${ }^{1} \mathrm{H}(400 \mathrm{MHz})$ and $\mathrm{NMR}^{13} \mathrm{C}(100 \mathrm{MHz})$ spectra were recorded on Brucker-Advance DPX400 spectrometer, with DMSO-d $\mathrm{d}_{6}$ (Aldrich) as solvent and TMS (Merck) as internal reference.

\section{Essential oil extraction and GC-MS analysis}

Fresh leaves (483.45 g) and fresh inflorescences (296.26 g) were submitted separately to hydrodistillation and cohobation in Clevenger apparatus for $3.5 \mathrm{~h}$. After extraction, each essential oil was separate from water by decantation and was desiccated through slow percolation in simple filtration system containing $\mathrm{Na}_{2} \mathrm{SO}_{4}$ anhydrous (Synth). The essential oils were maintained under low temperature and protected from light until the moment of analysis.

The GC-MS analyses were carried out on a Shimadzu GC-MS-QP2010 gas chromatography-mass spectrometer equipped with capillary column DB5-MS Agilent $(30 \mathrm{~m}$ x $0.25 \mathrm{~mm}$, film thickness 0.25 $\mu \mathrm{m})$ under the following conditions: Helium was used as the carrier gas at pressure of $81.90 \mathrm{kPa}$, with flow of $1.33 \mathrm{~mL} / \mathrm{min}$; the temperature in the injector was $250{ }^{\circ} \mathrm{C}$; the temperature of the oven progressed from 60 to $240{ }^{\circ} \mathrm{C}$ to $3{ }^{\circ} \mathrm{C} / \mathrm{min}$. The ionization mode used was the electronic impact at $70 \mathrm{eV}$. Later, under the same experimental conditions, each oil was coinjected with a homologous series of linear hydrocarbons $\left(\mathrm{C}_{9}\right.$ $\mathrm{C}_{25}$ )-Alltech, to accomplishment calculations of the retention index (RI) of each constituent of the samples applying Van Den Dool \& Kratz Equation (1963). The compounds identification was performed by analysis and comparison of the mass spectra with database of Wiley 7 library and by comparison of RI with those of the literature (Adams, 1995; Tellez et al., 1999; Araujo et al.; 2003; Bin Ahmad \& Bin Jantan, 2003; Choi, 2003; Hognadottir \& Rouseff, 2003; Kariot et al., 2003; Priestap et al., 2003; El-Sayed et al., 2005; Sylvestre et al., 2006; Machado et al., 2007; Morteza-Semnani et al., 2007; Torres et al., 2008; Brasil et al., 2009; Chaichana et al., 2009; Moghtader, 2009; Lamien-Meda et al., 2010). The relative quantification of the components of each sample was obtained through the relative area of the peaks in the chromatograms.

\section{Results and Discussion}

Eleven compounds were obtained from organic extracts from aerial parts (leaves plus branches plus inflorescences) of $A$. fastigiatum: three compounds from
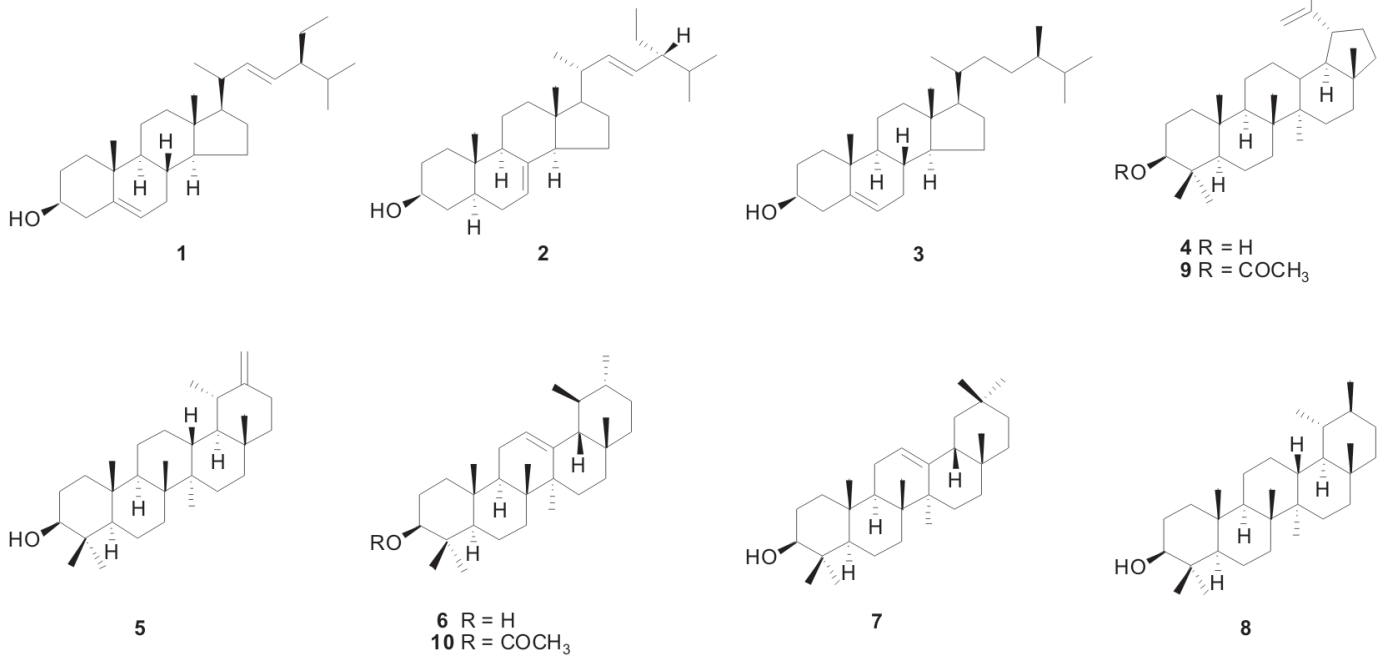
Table 1. Relative retention (RR) of steroids standards, relative retention and relative abundance of steroids isolated from the hexane extract of the aerial parts of Ageratum fastigiatum.

\begin{tabular}{ccccc}
\hline Steroid & $\begin{array}{c}\text { RR of steroids } \\
\text { standards }^{\mathrm{a}}\end{array}$ & $\begin{array}{c}\mathrm{t}_{\mathrm{R}}(\mathrm{min})^{\mathrm{b}} \text { of steroids isolated } \\
\text { from } \text { A. fastigiatum }\end{array}$ & $\begin{array}{c}\text { RR of steroids isolated } \\
\text { from } \text { A. fastigiatum }^{\mathrm{a}}\end{array}$ & $\begin{array}{c}\text { Relative abundance (\%) of steroids } \\
\text { isolated from } \text { A. fastigiatum }^{\text {fatum }}\end{array}$ \\
\hline campesterol & 1.641 & 19.667 & 1.641 & 0.42 \\
stigmasterol & 1.691 & 20.324 & 1.695 & 55.92 \\
chondrillasterol & 1.806 & 21.686 & 1.809 & 39.64 \\
\hline
\end{tabular}

internal standard used to calculate RR: 5 - $\alpha$-cholestane, with $\mathrm{t}_{\mathrm{R}}=11.984 \mathrm{~min} .{ }^{\mathrm{b}} \mathrm{t}_{\mathrm{R}}$ : retention time in minutes.

hexane extract, seven compounds from ethyl acetate extract and one compound from ethanol extract.

The fractionation of the hexane extract led to the isolation and the identification of three steroids in mixture, 1-3. The stigmasterol $\mathbf{1}$ was the majority constituent (55.92\%), following for the chondrillasterol $2(39.64 \%)$ and by campesterol $3(0.42 \%)$. RRs of the components of the mixture compared RRs of steroids standards found in the Table 1. In the hexane extract were identified $95.98 \%$ of the mixture constituents. This is the first study which identifies steroids in organic extract of A. fastigiatum.

The chloroform phase, obtained from the partition of the ethyl acetate extract, after successive preparative chromatography yielded a mixture of seven triterpenes 4-10, identified through GC-MS and RR obtained by GC (Table 2). The lupeol 4, major component of mixture $(51.06 \%)$, was previously identified in extracts of aerial parts of the plant (Bohlmann et al., 1981; Bohlmann et al., 1983), as well as the taraxasterol 5 (Bohlmann et al., 1983) that in our study presents relative quantification of $2.01 \%$. All other identified triterpenes in the ethyl acetate extract were not detected in previous studies accomplished with that vegetable species: $\alpha$-amyrin $6(30.39 \%), \beta$-amyrin $7(5.75 \%)$, pseudotaraxasterol $8(0.71 \%)$, lupeol acetate $9(0.38 \%)$ and $\alpha$-amyrin acetate $10(0.21 \%)$. In the ethyl acetate extract were identified $90.51 \%$ constituents of the mixture. The triterpenes found are characteristic of the Asteraceae family which presents in all the tribes those metabolites with oleane skeletons (such as $\beta$-amyrin), ursane ( $\alpha$-amyrin, taraxasterol, pseudotaraxasterol) and lupeane (lupeol) (Hegnauer, 1977; Zdero \& Bohlmann, 1990).

From the preparative chromatography of the ethanol extract a coumarin was isolated and identified as ayapin or 6,7-methylene-dioxide coumarin 11. The structure of compound $\mathbf{1 1}$ was elucidated as coumarin using $\mathrm{NMR}^{1} \mathrm{H}$ and ${ }^{13} \mathrm{C}$ spectral data compared with the literature (Sun et al., 2007; Canuto et al., 2010). The ayapin was previously isolated from extracts of aerial parts and roots of the plant (Bohlmann et al., 1983). In fact, chemosystematic studies indicate that coumarins presents wide occurrence in Asteraceae family, and ayapin is found in Eupatorieae tribe (Hegnauer, 1977; Zdero \& Bohlmann 1990; Ribeiro \& Kaplan, 2002).<smiles>O=c1ccc2cc3c(cc2o1)OCO3</smiles>

11

The essential oils of leaves and of inflorescences of $A$. fastigiatum obtained by hydrodistillation presented yields of 0.04 and $0.07 \%$ $(\mathrm{m} / \mathrm{m})$, respectively. That difference of $42.86 \%$ in the yield can be associated to variations in biosynthesis and/or in storage of secondary metabolites by cells of different tissues. This has been observed in some vegetable species in relation to their essential oils from

Table 2. Relative retention (RR) of triterpenes standards, relative retention and relative abundance of triterpenes isolated from the ethyl acetate extract of aerial parts of Ageratum fastigiatum.

\begin{tabular}{|c|c|c|c|c|}
\hline Triterpene & $\begin{array}{c}\mathrm{RR}^{\mathrm{a}} \text { of } \\
\text { triterpenes } \\
\text { standards }\end{array}$ & $\begin{array}{c}\mathrm{t}_{\mathrm{R}}(\min )^{\mathrm{b}} \text { of triterpenes } \\
\text { isolated from } \\
\text { A. fastigiatum }\end{array}$ & $\begin{array}{l}\mathrm{RR}^{\mathrm{a}} \text { of triterpenes } \\
\text { isolated from } \\
\text { A. fastigiatum }\end{array}$ & $\begin{array}{c}\text { Relative abundance }(\%) \text { of } \\
\text { triterpenes isolated from } \\
\text { A. fastigiatum }\end{array}$ \\
\hline$\beta$-amyrin & 2.181 & 30.796 & 2.185 & 5.75 \\
\hline$\alpha$-amyrin & 2.366 & 33.498 & 2.376 & 30.39 \\
\hline lupeol & 2.387 & 33.883 & 2.404 & 51.06 \\
\hline$\alpha$-amyrin acetate & 2.475 & 34.941 & 2.493 & 0.21 \\
\hline lupeol acetate & 2.506 & 35.364 & 2.509 & 0.38 \\
\hline pseudotaraxasterol & 2.664 & 37.627 & 2.669 & 0.71 \\
\hline taraxasterol & 2.722 & 38.416 & 2.725 & 2.01 \\
\hline
\end{tabular}

ainternal standard used to calculate RR: 5 - $\alpha$-cholestane, with $t_{R}=14.093$ min. ${ }^{b} t_{R}$ : retention time in minutes. 
Table 3. Retention index (RI) and relative percentage composition of the essential oil from leaves and of essential oil from inflorescences of Ageratum fastigiatum.

\begin{tabular}{|c|c|c|c|c|c|}
\hline \multirow[b]{2}{*}{ Constituents $^{\mathrm{a}}$} & \multirow[b]{2}{*}{ RI literatura ${ }^{\mathrm{b}}$} & \multicolumn{2}{|c|}{ Essential oil from leaves } & \multicolumn{2}{|c|}{ Essential oil from inflorescences } \\
\hline & & $\mathrm{RI}_{\text {calculated }}$ & $\begin{array}{l}\text { Relative amount } \\
(\%)\end{array}$ & $\mathrm{RI}_{\text {calculated }}$ & $\begin{array}{l}\text { Relative amount } \\
(\%)\end{array}$ \\
\hline$\alpha$-thujene & $923,931^{\mathrm{c}}, 933$ & 924 & 0.2 & 931 & 0.18 \\
\hline$\alpha$-pinene & $927,933,934,939^{c}, 941$ & 932 & 51.27 & 937 & 41.18 \\
\hline camphene & $952,953^{\mathrm{c}}, 954$ & 948 & 0.25 & 948 & 0.18 \\
\hline sabinene & $965,973,976^{c}, 977$ & 971 & 1.80 & 970 & 0.90 \\
\hline$\beta$-pinene & $980^{c}, 981,984$ & 977 & 3.23 & 976 & 5.01 \\
\hline myrcene & $991^{\mathrm{c}}, 992,993,994,995$ & 987 & 1.92 & 987 & 0.90 \\
\hline limonene & $1031^{\mathrm{c}}, 1036,1039$ & 1027 & 17.18 & 1027 & 16.51 \\
\hline trans- $\beta$-ocimene & $1050^{c}, 1051$ & 1043 & 4.68 & 1043 & 4.93 \\
\hline linalool & $1096,1098^{c}, 1104,1107,1112,1127$ & - & - & 1099 & 0.16 \\
\hline lavandulol & $1166^{\mathrm{c}}$ & - & - & 1161 & 0.46 \\
\hline terpin-4-ol & $1177^{\mathrm{c}}, 1178,1181,1198$ & 1178 & 0.24 & 1178 & 0.39 \\
\hline$\alpha$-terpinyl acetate & $1350^{c}, 1352,1354$ & - & - & 1356 & 1.61 \\
\hline$\alpha$-copaene & $1353,1375,1376^{c}, 1377,1391$ & 1372 & 0.66 & 1372 & 1.17 \\
\hline $\begin{array}{c}\text { trans- } \beta- \\
\text { caryophyllene }\end{array}$ & $\begin{array}{c}1414,1418^{c}, 1421,1422,1428 \\
1437,1467\end{array}$ & 1414 & 3.18 & 1414 & 5.78 \\
\hline$\alpha$-humulene & $1437,1452,1454^{\mathrm{c}}, 1472$ & 1450 & 1.35 & 1450 & 1.72 \\
\hline germacrene D & $1480^{c}, 1482,1485,1486,1497$ & 1476 & 9.09 & 1476 & 8.23 \\
\hline$\alpha$-muurolene & $1499^{c}, 1502,1505$ & - & - & 1494 & 0.19 \\
\hline germacrene A & $1502,1503^{\mathrm{c}}, 1560$ & 1502 & 0.10 & - & - \\
\hline$\alpha$-amorphene & 1485,1506 & - & - & 1506 & 0.27 \\
\hline$\gamma$-cadinene & $1512,1513^{\mathrm{c}}, 1516,1521$ & 1513 & 0.45 & 1508 & 0.11 \\
\hline spathulenol & $1552,1575,1576^{\mathrm{c}}, 1579$ & 1571 & 0.11 & 1575 & 0.34 \\
\hline viridiflorol & $1590^{\mathrm{c}}, 1593,1615$ & 1615 & 2.33 & 1615 & 4.56 \\
\hline $\begin{array}{l}\text { allo-aromadendrene } \\
\text { epoxide }\end{array}$ & $1641,1642,1646$ & - & - & 1632 & 0.92 \\
\hline
\end{tabular}

${ }^{\mathrm{a}}$ Constituents ordered in agreement with the retention time in column DB-5MS ${ }^{\mathrm{b}} \mathrm{RI}$ found in the literature, obtained in non-isothermal analyses, in columns DB-5MS or DB-5, under several analytical conditions. ${ }^{\circ} \mathrm{RI}$ are the same ones observed in Adams (1995).

different tissues (Koketsu et al., 1997; Botrel et al., 2009; Del-Vechio-Vieira et al., 2009b). In the specific case of essential oil of leaf origin, the yield obtained in our work is low when compared to other studies, that presented yields between 0.40 to $1.20 \%$, also using hydrodistillation as extractive procedure (Del-VechioVieira et al., 2009a; Del-Vechio-Vieira et al., 2009b). However, the variations observed among the yields might have happened because the different population and geographical origins (the vegetable was collected in São João del Rei-MG, in previous researches) and different collection periods (month and year) of materials vegetables. There aren't previously chemical studies accomplished with essential oil extracted from the inflorescences this vegetable species.

The chemical components identified in each sample of essential oil as well as their retention indexes and their relative amounts are in the Table 3 . Were identified $98.04 \%$ and $95.70 \%$ of components of the essential oil of leaves and of essential oil from inflorescences, respectively. Significant quantitative differences were not observed between the major constituents of both essential oils: $\alpha$-pinene, limonene, germacrene $\mathrm{D}$, trans- $\beta$-caryophyllene, $\beta$-pinene and $\beta$-ocimene. However, qualitative differences among the minor constituents of essential oils can be observed: linalool, lavandulol, $\alpha$-terpinyl acetate, $\alpha$-muurolene, $\alpha$-amorphene and allo-aromadendrene epoxide in essential oil of inflorescences, not detected in the leaves; and, the germacrene A, only observed in the essential oil of the leaves.

When the our results are compared with previous studies it can be verified the qualitative and quantitative differences in the chemical composition of 
essential oils of leaves.

In research accomplished by Del-Vechio-Vieira et al. (2009a) the essential oil was obtained from dried leaves, being identified thirty chemical components, of which the majority ones were germacrene D (24.15\%), the $\alpha$-humulene $(11.15 \%)$, the $\beta$-cedrene $(10.63 \%)$ and $\alpha$-pinene $(9.50 \%)$. In the current study the $\beta$-cedrene was not detected, the $\alpha$-humulene appear in small amount $(1.35 \%)$ and the germacrene D was not majority terpene $(9.09 \%)$, being the $\alpha$-pinene $(51.27 \%)$ the main component observed. More abundant components in our research (trans- $\beta$-caryophyllene, $\beta$-pinene and $\beta$-ocimene) were not detected by Del-Vechio-Vieira et al. (2009a). Among the factors that could influence those differences between the two researches we can mention the use of fresh material in our study and the use of dry leaves on the previous work.

In the second study of Del-Vechio-Vieira et al. (2009b) with essential oil extracted from fresh leaves were identified 20 terpenoids, being the majority ones of germacrene D $(20.00 \%), \beta$-caryophyllene (19.60\%), 1,10-di-epi-cubenol (15.40\%), $\alpha$-humulene $(4.90 \%)$. These sesquiterpenes, we find in our work the germacrene D $(9.09 \%)$, $\beta$-caryophyllene $(3.18 \%)$ and $\alpha$-humulene $(1.35 \%)$, not representing, however, the major components. Still, the most abundant components in our essential oil, such as the $\alpha$-pinene (51.27\%) and the limonene $(17.18 \%)$, were not observed by these authors. Differences between vegetable populations and geographic origin and time for collection of leaves might have contributed to the differences observed in chemical composition of essential oils studied, among other factors.

Therefore, quantitative and qualitative chemical variations were observed in different studies of A. fastigiatum performed with individuals from different populations, collected in different regions and seasons. However, there is also certain constancy, at least qualitative, in the chemical composition of essential oils of leaves from this vegetable species analyzed in our work and in other studies (DelVechio-Vieira et al., 2009a; Del-Vechio-Vieira et al., $2009 b$ ), for example, the presence of $\beta$-caryophyllene, $\alpha$-copaene, $\alpha$-humulene, germacrene D, spathulenol, among others. These last three sesquiterpenes were also found in organic extract of the aerial parts of $A$. fastigiatum collected in Goiás (Bohlmann et al., 1983). Taraxasterol, lupeol and ayapin were also isolated from extracts of this vegetable species (Bohlmann et al., 1981; Bohlmann et al., 1983), which coincides with our results.

\section{Acknowledgments}

The authors are grateful to Prof. Dr. Antonio Gilberto Ferreira (Departamento de Química - UFSCar) for obtaining the NMR spectra and FAPEMIG for financial support (CDS-1645/05).

\section{References}

Adams RP 1995. Identification of essential oil components by gas chromatography/ mass spectroscopy. Illinois: Allured Publishing Corporation.

Almeida AM, Prado PI, Lewinsohn TM 2004. Geographical distribution of Eupatorieae (Asteraceae) in southeastern and south Brazilian mountain ranges. Plant Ecol 174: 163-181.

Araujo ECC, Silveira ER, Lima MAS, Neto MA, Andrade IL, Lima MAA, Santiago GPS, Mesquita ALM 2003. Insecticidal activity and chemical composition of volatile oils from Hyptis martiusii Benth. J Agr Food Chem 51: 3760-3762.

Bin Ahmad F, Bin Jantan I 2003. Chemical constituents of the essential oils of Goniothalamus uvariodes King. Flavour Fragr J 18: 128-130.

Bohlmann F, Ahmed M, King RM, Robinson H 1981. Labdane and eudesmane derivatives from Ageratum fastigiatum. Phytochemistry 20: 1434-1435.

Bohlmann F, Ludwig GW, Jakupovic J, King RM, Robinson H 1983. A daucanolide and further farsene derivatives from Ageratum fastigiatum. Phytochemistry 22: 983986.

Botrel PP, Pinto JEBP, Figueiredo FC, Bertolucci SKV, Ferri PH 2009. Teor e composição química do óleo essencial de Hyptis marrubioides Epling (Lamiaceae) em diferentes genótipos. Rev Bras Pl Med 11: 164169.

Brasil DSB, Muller AH, Guilhom GMSP, Alves CN, Andrade EHA, Silva JKR, Maia JGS 2009. Essential Oil Composition of Croton palanostigma Klotzsch from North Brazil. J Braz Chem Soc 20: 1188-1192.

Canuto KM, Silveira ER, Bezerra AME 2010. Estudo fitoquímico de espécimens cultivados de cumaru (Amburana cearensis A. C. Smith). Quím Nova 33: 662-666.

Castro HG, Oliveira LO, Barbosa LCA, Ferreira FA, Silva DJH, Mosquim PR, Nascimento EA 2004. Teor e composição do óleo essencial de cinco acessos de mentrasto. Quím Nova 27: 55-57.

Chaichana J, Niwatananum W, Vejabhikul S, Somna S, Chansakaow S 2009. Volatile constituents and biological activities of Gardenia jasminoides. $J$ Health Res 23: 141-145.

Choi HS 2003. Character impact odorants of citrus hallabong [(C. unshiu Marcov x C. sinensis Osbeck) $\mathrm{x} C$. reticulata Blanco] cold-pressed peel oil. J Agr Food Chem 51: 2687-2692.

Del-Vechio-Vieira G, Sousa OV, Yamamoto CH, Kaplan MAC 2007. Atividades antinociceptiva e antimicrobiana de Ageratum fastigiatum (Gardn.) R.M. King et H. Rob. 
(Asteraceae). Rev Bras Farmacogn 88: 181-184.

Del-Vechio-Vieira G, Barbosa MVD, Lopes BC, Sousa OV, Santiago-Fernandes LDR, Esteves RL, Kaplan MAC 2008. Caracterização morfoanatômica de Ageratum fastigiatum (Asteraceae). Rev Bras Farmacogn 18: 769-776.

Del-Vechio-Vieira G, Sousa OV, Miranda MA, Senna-Valle L, Kaplan MAC 2009a. Analgesic and anti-inflammatory properties of essential oil from Ageratum fastigiatum. Braz Arch Biol Technol 52: 1115-1121.

Del-Vechio-Vieira G, Sousa OV, Yamamoto CH, Kaplan MAC 2009b. Chemical composition and antimicrobial activity of the essential oils of Ageratum fastigiatum (Asteraceae). Rec Nat Prod 3: 52-57.

El-Sayed AM, Heppelthwaite VJ, Manning LM, Gibb AR, Suckling DM 2005. Volatile constituents of fermented sugar baits and their attraction to lepidopteran species. $J$ Agr Food Chem 53: 953-958.

Gobbo-Neto L, Lopes NP 2007. Plantas medicinais: fatores de influência no conteúdo de metabólitos secundários. Quím Nova 30: 374-381.

Gonçalves LD, Grael CFF, Lopes NP, Siriane SEQ, Archanjo FC, Praxedes MPS, Dias MEC 2007. Estudo fitoquímico de Ageratum fastigiatum: planta do cerrado e campo rupestre utilizada na medicina popular na região do Alto Jequitinhonha. IX Jornada Acadêmica, Científica e Tecnológica da UFVJM. Diamantina, Brasil.

Guimarães AJM, Araújo GM, Corrêa GF 2002. Estrutura fitossociológica em área natural e antropizada de uma vereda de Uberlândia, MG. Acta Bot Bras 16: 317 329.

Hegnauer R 1977. The chemistry of the Compositae. In Heywood VH, Harborne JB, Turner BL (eds) The biology and chemistry of the Compositae. vol. I. London: Academic Press Inc. Ltd., p. 283-335.

Hognadottir A, Rouseff RL 2003. Identification of aroma active compounds in orange essence oil using gas chromatography - olfactometry and gas chromatography - mass spectrometry. J Chromatogr A 998: 201-211.

Karioti A, Skaltsa H, Demetzos C, Perdetzoglou D, Economakis CD, Salem AB 2003. Effect of nitrogen concentration of the nutrient solution on the volatile constituents of leaves of Salvia fruticosa Mill. in solution culture. J Agr Food Chem 51: 6505-6508.

Koketsu M, Gonçalves SL, Godoy RLO, Lopes D, Morsbach N 1997. Óleos essenciais de cascas e folhas de canela (Cinnamomum verum Presl) cultivada no Paraná. Ciênc Tecnol Aliment 17: 281-285.

Lamien-Meda A, Schmiderer C, Lohwasser U, Börner A, Franza C, Novaka J 2010. Variability of the essential oil composition in the sage collection of the Genebank Gatersleben: a new viridiflorol chemotype. Flavour Fragr J 25: 75-82.
Lima HRP, Kaplan MAC, Cruz AVM 2003. Influência dos fatores abióticos na produção e variabilidade de terpenóides em plantas. Floresta Ambient 10: 71-77.

Machado CCB, Bastos DHM, Janzantti NS, Facanali R, Marques MOM, Franco MRB 2007. Determinação do perfil de compostos voláteis e avaliação do sabor e aroma de bebidas produzidas a partir da erva-mate (Ilex paraguariensis). Quím Nova 30: 513-518.

McNair HM, Bonelli EJ 1969. Basic gas chromatography. California: Varian Aerograph.

Moghtader M 2009. Chemical composition of the essential oil of Teucrium polium L. from Iran. Am-Euras J Agric \& Environ Sci 5: 843-846.

Morteza-Semnani K, Saeedi M, Akbarzadeh M 2007. Essential oil composition of Teucrium scordium L. from Iran. Acta Pharm 57: 499-504.

Priestap HA, Van Baren CM, Di Leo Lira P, Coussio JD, Bandoni AL 2003. Volatile constituents of Aristolochia argentina. Phytochemistry 63: 221-225.

Ribeiro CVC, Kaplan MAC 2002. Tendências evolutivas de famílias produtoras de cumarinas em Angiospermae. Quím Nova 25: 533-538.

Sun XB, Zhao PH, Xu YJ, Sun LM, Cao MA, Yuan CS 2007. Chemical constituents from the roots of Polygonum bistorta. Chem Nat Compd 43: 563-566.

Sylvestre M, Pichette A, Longtin A, Nagau F, Legault J 2006. Essential oil analysis and anticancer activity of leaf essential oil of Croton flavens L. from Guadeloupe. $J$ Ethnopharmacol 103: 99-102.

Tellez MR, Canel C, Rimando AM, Duke SO 1999. Differential accumulation of isoprenoids in glanded and glandless Artemisia annua L. Phytochemistry 52: 1035-1040.

Torres RNS, Lopes JAD, Neto JMM, Citó AMGL 2008. Constituintes voláteis de própolis piauiense. Quím Nova 31: 479-485.

Van Den Dool H, Kratz PD 1963. A generalization of the retention index system including linear temperature programmed gas-liquid partition chromatography. $J$ Chromatogr 11: 463-471.

Wagner H, Bladt S 1996. Plant drug analysis - a thin layer chromatography atlas $2 \mathrm{ed}$. Berlin: Springer.

Zdero C, Bohlmann F 1990. Systematic and evolution within the Compositae seen with the eyes of a chemistry. $P l$ Syst Evol 171: 1-14.

\section{*Correspondence}

Cristiane F. F. Grael

Departamento de Farmácia, Faculdade de Ciências Biológicas e da Saúde, Universidade Federal dos Vales do Jequitinhonha e Mucuri

Campus JK, Rodovia MGT 367, km 583, nº 5000, Bairro Alto da Jacuba, 39100-000 Diamantina-MG, Brazil

cris.grael@ufvjm.edu.br

Tel. +553835321234 